\title{
FORMULATION AND IN VITRO EVALUATION OF ORAL DISINTEGRATING TABLETS OF AMLODIPINE BESYLATE
}

\author{
S. JAYA*, V. AMALA \\ Department of Pharmaceutics, Anurag Pharmacy College, Ananthagiri, Kodad, Suryapet 508206, Telangana, India \\ Email: jayamay24@gmail.com
}

Received: 13 Feb 2018, Revised and Accepted: 19 Nov 2018

ABSTRACT

Objective: The present investigation was undertaken with an objective of formulating oral disintegrating tablets of amlodipine besylate to enhance convenience and compliance of the elderly and pediatric patients for better therapeutic efficacy.

Methods: The tablets were prepared by using direct compression method and evaluated for weight variation, hardness, friability, wetting time, disintegration time and in vitro drug release study. Prepared tablets were evaluated for compatibility by Fourier transform infrared spectroscopy.

Results: Fourier transform infrared spectroscopy studies revealed that there was no physicochemical interaction between amlodipine besylate and other excipients. All the tablets hardness was found to be around $3.5 \mathrm{~kg} / \mathrm{cm}^{2}$ and friability of all the formulations was less than $1 \%$, Drug content in all the formulations was found in the range of $97.05 \%$ to $99.13 \%$.

Conclusion: The study clearly indicated that the type and concentration of superdisintegrants plays an important role in disintegration and dissolution of drug from oral disintegrating tablets. Among all the formulations, the maximum percentage of drug release and less disintegration time was found in F9 formulation containing $4 \%$ of crospovidone.

Keywords: Oral disintegrating tablets, Amlodipine besylate, ODTs, Crospovidone, Croscarmellose sodium

(C) 2019 The Authors. Published by Innovare Academic Sciences Pvt Ltd. This is an open access article under the CC BY license (http://creativecommons.org/licenses/by/4.0/) DOI: http://dx.doi.org/10.22159/ijap.2019v11i1.28457

\section{INTRODUCTION}

Solid dosage forms are the most popular and preferred drug delivery systems. Most of the oral pharmaceutical dosage forms like conventional tablets and capsules are formulated to be swallowed or chewed. Many pediatric, geriatric and bedridden patients find difficulty in swallowing (i.e., dysphagia) these dosage forms [1]. It is estimated that $50 \%$ of the population is affected by this problem which results in a high incidence of non-compliance and ineffective therapy [2]. The concept of oral disintegrating drug delivery system emerged from the desire to improve patient compliance. An oral disintegrating tablet offers quick disintegration and dissolution of the tablet in the oral cavity within a minute without the need of water. According to European pharmacopoeia, oral disintegrating tablet should disperse or disintegrate in less than three minutes. The medication can be absorbed partially or entirely into the systemic circulation from blood vessels in the oral mucosa; it can be swallowed as a solution to be absorbed from the gastrointestinal tract $[3,4]$.

Angina pectoris is chest pain due to ischemia of heart muscle due to obstruction or spasm of the coronary arteries. Amlodipine besylate is a long-acting calcium channel blocker mainly used in the treatment of chronic stable angina vasospastic angina and hypertension [5]. Amlodipine is listed in World health organization (WHO) under the list of essential medicines as antihypertensive medicine in $5 \mathrm{mg}$ tablet. It inhibits the transmembrane influx of calcium ion into vascular smooth muscle and cardiac muscle. Its efficacy is not only limited to the treatment of cardiovascular diseases as it has shown to posses antioxidant activity and plays an important role in apoptosis. Peak plasma concentrations are reached 6-12 h. It has oral bioavailability of $64-90 \%$ and half-life of about 30 $50 \mathrm{~h}$ [6]. Amlodipine besylate is slightly soluble drug the rate of absorption is controlled by the rate of dissolution. The rate of dissolution can be increased by the use of super disintegrants [7]. Oral disintegrating tablets are designed to be placed in mouth allowed to disperse or dissolve in the saliva and then swallowed without the aid of water. As the tablet disintegrates in the mouth, this could enhance the clinical effect of the drug through pre-gastric absorption [8]. The objective of the present study was to deliver the drug at a faster rate and to provide immediate onset of action in a shorter period of time with improved bioavailability. The basic approach in the development of oral disintegrating tablets is the use of superdisintegrants like croscarmellose sodium, sodium starch glycolate and crospovidone.

\section{MATERIALS AND METHODS}

Amlodipine besylate was obtained from Yarrow chemicals, Mumbai. Sodium starch glycolate, croscarmellose sodium and crospovidone, microcrystalline cellulose, and mannitol were purchased from Aman scientific industries, Vijayawada. Talc and magnesium stearate were purchase from Loba Chemie Pvt. Ltd. All other chemicals/solvents used were of analytical grade.

\section{Estimation of ambroxol hydrochloride}

Lab India double beam UV-Visible spectrophotometer was used to estimate amlodipine besylate in pure form and formulations developed using various concentrations of super disintegrants at $237.5 \mathrm{~nm}$.

An analytical method for construction of calibration curve of amlodipine besylate

$100 \mathrm{mg}$ of amlodipine besylate was dissolved in $100 \mathrm{ml}$ of $0.01 \mathrm{~N}$ hydrochloric acid. $10 \mathrm{ml}$ of this solution was further diluted to 100 $\mathrm{ml}$ of $0.01 \mathrm{~N}$ hydrochloric acid to obtain $100 \mu \mathrm{g} / \mathrm{ml}$ From this solution $(100 \mu \mathrm{g} / \mathrm{ml})$ suitable working solutions of different concentrations of $3,6,9,12,15$ and $18 \mu \mathrm{g} / \mathrm{ml}$ were prepared. The absorbance of these dilutions was measured at the determined lambda max of $237.5 \mathrm{~nm}$. The standard graph of concentration versus absorbance was then plotted. Each point is an average of three determinations. Slope, y-intercept, and regression coefficients were calculated [9].

\section{Drug-excipient compatibility study}

Fourier transform infrared spectroscopic (FTIR) studies were conducted to know the compatibility between drug and excipients. In these studies pure amlodipine besylate and its mixture with sodium starch glycolate, croscarmellose sodium, and crospovidone 
were grounded thoroughly with IR grade $\mathrm{KBr}$ and then compressed in a hydraulic press at a pressure of 10,000 psig, to get a disc. Each disc was scanned over a range of 400-4000 $\mathrm{cm}^{-1}$ using FTIR instrument (FTIR-1600, Shimadzu, Japan). The characteristic peaks were observed and recorded.

\section{Preparation of oral disintegrating tablets}

Oral disintegrating tablets of amlodipine besylate were prepared by direct compression method. All the ingredients listed in table 1 were accurately weighed and passed through a \# 60 sieve. Amlodipine besylate $(10 \mathrm{mg})$ was mixed with various concentrations of super disintegrants, microcrystalline cellulose, and mannitol. Then magnesium stearate and talc were added to the above blend.

The flow property of the final blend was determined by measuring the angle of repose and carr's index and they were found to be satisfactory to allow the mixture to be directly compressed into tablets on a 12-station rotary tablet punching machine (M/s. CEMACH Machinery, Co. Pvt. Ltd., India) using $8 \mathrm{~mm}$ punch [10].

Table 1: Composition of oral disintegrating tablets of amlodipine besylate

\begin{tabular}{|c|c|c|c|c|c|c|c|c|c|}
\hline Ingredients (mg/tablet) & F1 & F2 & F3 & F4 & F5 & F6 & F7 & F8 & F9 \\
\hline Amlodipine besylate & 10 & 10 & 10 & 10 & 10 & 10 & 10 & 10 & 10 \\
\hline Sodium starch glycolate & 2 & 4 & 6 & & & & & & \\
\hline Croscarmellose sodium & & & & 2 & 4 & 6 & & & \\
\hline Crospovidone & & & & & & & 2 & 4 & 6 \\
\hline Mannitol & 66 & 66 & 66 & 66 & 66 & 66 & 66 & 66 & 66 \\
\hline Microcrystalline cellulose & 65 & 63 & 61 & 65 & 63 & 61 & 65 & 63 & 61 \\
\hline Sodium sacharin & 1 & 1 & 1 & 1 & 1 & 1 & 1 & 1 & 1 \\
\hline Magnesium stearate & 3 & 3 & 3 & 3 & 3 & 3 & 3 & 3 & 3 \\
\hline Talc & 3 & 3 & 3 & 3 & 3 & 3 & 3 & 3 & 3 \\
\hline Total weight & 150 & 150 & 150 & 150 & 150 & 150 & 150 & 150 & 150 \\
\hline
\end{tabular}

\section{Micromeritic properties of the blended powder}

\section{Angle of repose}

The angle of repose of powder blend was determined by the fixed funnel method. The accurately weighed powder was taken in a funnel. The height of the funnel was adjusted in such a way that the tip of the funnel just touched the apex of the heap of the powder. The powder was allowed to flow through the funnel freely onto the surface. The diameter of the powder cone was measured and the angle of repose was calculated using the following equation [11].

$$
\tan \theta=\frac{\mathrm{h}}{\mathrm{r}}
$$

Where, $\theta=$ angle of repose,

$\mathrm{h}=$ height of the pile,

$r=$ radius of the pile base

\section{Bulk Density and tapped density}

A quantity of $2 \mathrm{~g}$ of powder from each formula, previously lightly shaken to break any agglomerates formed was introduced into a 10 $\mathrm{ml}$ measuring cylinder. After the initial volume was observed then calculate bulk density using the following formula [11].

$$
\text { Bulk density }=\frac{\text { weight of the powder }}{\text { bulk volume }}
$$

The cylinder was allowed to fall under its own weight onto a hard surface from the height of $2.5 \mathrm{~cm}$ at 2 second intervals. The tapping was continued until no further change in volume was noted. Tapped density was calculated using the following formula [11].

$$
\text { tapped density }=\frac{\text { weight of the powder }}{\text { tapped volume }}
$$

\section{Compressibility index}

The compressibility index of the powder blend was determined by Carr's compressibility index [11].

$$
\text { Carr's index }=\frac{\text { tapped density }- \text { bulk density }}{\text { tapped density }} \times 100
$$

\section{Evaluation of amlodipine besylate oral disintegrating tablets}

\section{Weight variation test}

To study weight variation, 20 tablets of each formulation were weighed using an electronic balance. Average weight was calculated then individual tablet weight was compared with average weight [12].

\section{Tablet hardness and friability}

For each formulation, the hardness of 6 tablets was determined using the Monsanto hardness tester. Friability of tablets was measured by using Roche Friabilator. Friability was evaluated from the percentage weight loss of 10 tablets tumbled in a friabilator at $25 \mathrm{rpm}$ for $4 \mathrm{~min}$. The tablets were deducted and the loss in weight caused by fracture or abrasion was recorded as the percentage weight loss. Friability below $1 \%$ was considered acceptable [12].

$$
\text { Friability }=\frac{\text { Initial weight }- \text { Final weight }}{\text { Initial weight }} \times 100
$$

\section{Uniformity of drug content}

10 Tablets were weighed from each formulation and triturated in a mortar to a fine powder. Powder equivalent to $10 \mathrm{mg}$ of amlodipine besylate was extracted in $10 \mathrm{ml}$ of methanol and liquid was filtered. The drug content was determined by measuring the absorbance at $237.5 \mathrm{~nm}$ (using a UV-Visible spectrophotometer, Lab India) after appropriate dilutions with methanol. The drug content was determined using a calibration curve. The mean percentage drug content was calculated as the average of three determinations.

\section{Wetting time}

The wetting time of the tablets can be measured using a simple procedure. Five circular tissue papers of $10 \mathrm{~cm}$ diameter are placed in a petridish with a $10 \mathrm{~cm}$ diameter. $10 \mathrm{ml}$ of water containing amaranth, a water-soluble dye is added to petridish. A tablet is carefully placed on the surface of the tissue paper. The time required for water to reach the upper surface of the tablet is noted as a wetting time [13]

\section{Water absorption ratio}

A piece of tissue paper folded twice was placed in a small petridish containing $6 \mathrm{ml}$ of water. A tablet was put on the tissue paper and allowed to completely wet. The wetted tablet was then weighed. Water absorption ratio, $\mathrm{R}$ was calculated using the following equation [14].

$$
\mathrm{R}=\frac{\mathrm{Wa}-\mathrm{Wb}}{\mathrm{Wb}} \times 100
$$

Where,

$\mathrm{W}_{\mathrm{a}}=$ Weight of tablet after water absorption
$\mathrm{W}_{\mathrm{b}}=$ Weight of tablet before water absorption 


\section{In-vitro dispersion time}

The amount of saliva available in the oral cavity is very limited (usually less than $6 \mathrm{ml}$ ). In a simplest method, $6 \mathrm{ml}$ of phosphate buffer of pH 6.8 was taken in a $25-\mathrm{ml}$ measuring cylinder. The temperature was maintained at $37 \pm 2^{\circ} \mathrm{C}$. An oral disintegrating tablet was placed into it and time required for complete disintegration of the tablet was noted [15]

\section{In vitro drug release studies}

In vitro drug release studies were carried out using Type II-USP dissolution test apparatus, Paddle (DBK dissolution testing apparatus, Mumbai, India) at $75 \mathrm{rpm}$. The dissolution medium consists of $500 \mathrm{ml}$ of $0.01 \mathrm{~N}$ hydrochloride acid. The medium was maintained at $37 \pm 0.5$ ${ }^{\circ} \mathrm{C}$. Aliquot $(5 \mathrm{ml})$ of the solution was collected from the dissolution apparatus at 5, 10, 15, 20, 25 and $30 \mathrm{~min}$. and replenishment with an equal volume of fresh dissolution medium. The withdrawn samples were analyzed by an UV-Visible spectrophotometer (Lab India) at $237.5 \mathrm{~nm}$ using $0.01 \mathrm{~N}$ hydrochloride acid as a blank. Aliquots were withdrawn from a zone midway between the surface of dissolution medium and the top of rotating paddle [16].

\section{RESULTS AND DISCUSSION}

\section{An analytical method for construction of a calibration curve}

In order to conduct the in vitro drug dissolution studies calibration curve was plotted to determine $\mathrm{R}^{2}$ and the equation of straight line is used to calculate drug release. Calibration curves of amlodipine besylate in $0.01 \mathrm{~N}$ hydrochloride acid was constructed at lambda max of $237.5 \mathrm{~nm}$ and is shown in the fig. 1

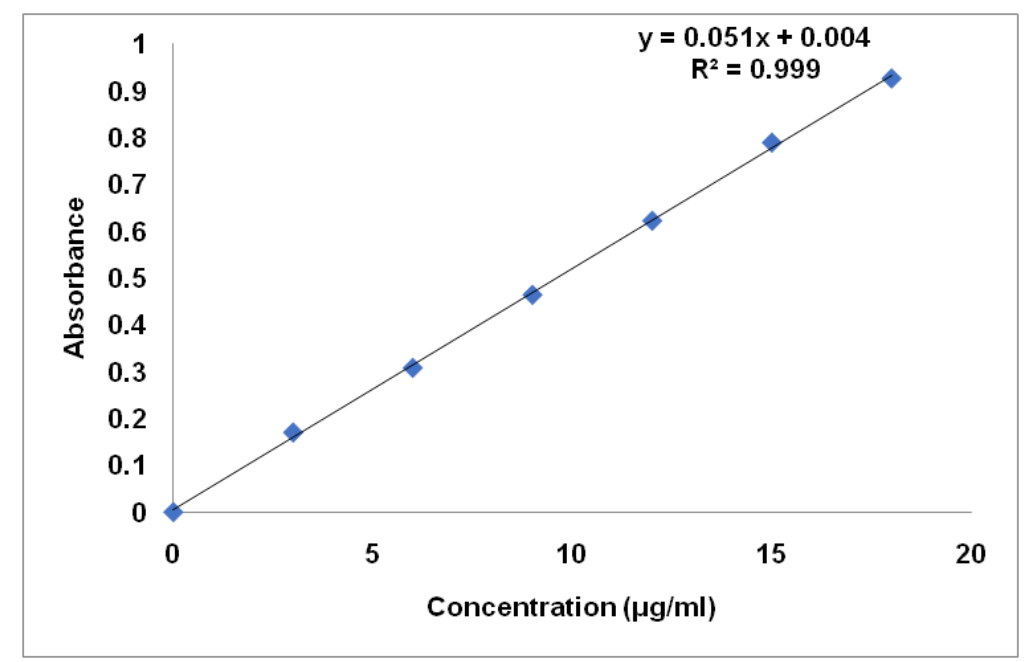

Fig. 1: Calibration curve of amlodipine besylate

Table 2: Micromeritic properties of the blended powder

\begin{tabular}{llllll}
\hline Formulation & Bulk density $\mathbf{( g m} / \mathbf{c c})$ & Tapped density $\mathbf{( g m / c c )}$ & Carr's index $(\mathbf{\%})$ & Hausner ratio & Angle of repose $(\boldsymbol{\theta})$ \\
\hline F1 & $0.43 \pm 0.07$ & $0.52 \pm 0.02$ & $16.09 \pm 0.04$ & $1.19 \pm 0.02$ & $27.5 \pm 0.01$ \\
F2 & $0.44 \pm 0.05$ & $0.51 \pm 0.03$ & $14.06 \pm 0.03$ & $1.16 \pm 0.01$ & $29.0 \pm 0.04$ \\
F3 & $0.45 \pm 0.01$ & $0.52 \pm 0.05$ & $14.12 \pm 0.04$ & $1.16 \pm 0.01$ & $27.7 \pm 0.03$ \\
F4 & $0.43 \pm 0.09$ & $0.52 \pm 0.08$ & $16.39 \pm 0.03$ & $1.19 \pm 0.02$ & $29.7 \pm 0.04$ \\
F5 & $0.43 \pm 0.03$ & $0.51 \pm 0.09$ & $15.44 \pm 0.02$ & $1.18 \pm 0.03$ & $27.1 \pm 0.03$ \\
F6 & $0.44 \pm 0.03$ & $0.51 \pm 0.09$ & $12.74 \pm 0.07$ & $1.14 \pm 0.02$ & $28.3 \pm 0.06$ \\
F7 & $0.42 \pm 0.04$ & $0.51 \pm 0.04$ & $16.69 \pm 0.09$ & $1.20 \pm 0.07$ & $27.5 \pm 0.04$ \\
F8 & $0.42 \pm 0.05$ & $0.50 \pm 0.04$ & $15.71 \pm 0.03$ & $1.18 \pm 0.03$ & $28.0 \pm 0.01$ \\
F9 & $0.44 \pm 0.06$ & $0.51 \pm 0.04$ & $12.74 \pm 0.01$ & $1.14 \pm 0.04$ & $27.7 \pm 0.03$ \\
\hline
\end{tabular}

All the values are expressed as mean $\pm \mathrm{SD}$, where $\mathrm{n}=3$.

Oral disintegrating tablets of amlodipine besylate were prepared by direct compression method employing different concentrations of sodium starch glycolate, croscarmellose sodium and crospovidone. A total of nine formulations were designed. The formulation F1, F2, F3 having sodium starch glycolate as superdisintegrants. Formulation F4, F5, F6 having croscarmellose sodium as superdisintegrants. Formulations F7, F8, F9 having crospovidone as superdisintegrants. The flow properties of the powder blend were measured before compression. Results were shown in the table-2. The angle of repose values ranged from $27.1 \pm 0.03$ to $29.7 \pm 0.04$. Compressibility index and Hausner's ratio values were ranged from $12.74 \pm 0.01$ to $16.69 \pm 0.09$ and $1.14 \pm 0.02$ to $1.20 \pm 0.07$ respectively. Low Hausner's ratio (less than 1.25), compressibility index (less than $17 \%$ ) and angle of repose (less than $30^{\circ}$ ) indicated that the powder blend had good free-flowing property.

Oral disintegrating tablets of amlodipine besylate were prepared by direct compression technique. The prepared tablets were evaluated for different physicochemical properties and results were depicted in tables 3 and 4 . All the tablets passed weight variation test as the \% weight variation was within the pharmacopoeial limits of $\pm 7.5 \%$. Hardness $\left(3.6 \pm 0.11\right.$ to $\left.3.9 \pm 0.12 \mathrm{~kg} / \mathrm{cm}^{2}\right)$ and friability was less than $1 \%$ in all the formulations indicated that tablets had good mechanical resistance. Uniformity of the amlodipine besylate was determined by double bean UV spectrophotometer (LABINDIA), the content of amlodipine besylate was found within official limits. Drug content of all the tablets was found in the range of $97.05 \%$ to $99.13 \%$. 
Table 3: Evaluation parameters of oral disintegrating tablets of amlodipine besylate

\begin{tabular}{|c|c|c|c|c|}
\hline Formulation & Weight variation (mg)* & Hardness $\left(\mathrm{kg} / \mathrm{cm}^{2}\right) \#$ & Friability (\%) & Content uniformity (\%) \\
\hline F1 & $149.50 \pm 0.5$ & $3.6 \pm 0.11$ & 0.81 & 97.05 \\
\hline $\mathrm{F} 2$ & $150.50 \pm 0.2$ & $3.7 \pm 0.15$ & 0.64 & 97.11 \\
\hline F3 & $149.75 \pm 0.5$ & $3.9 \pm 0.12$ & 0.51 & 98.0 \\
\hline $\mathrm{F} 4$ & $149.25 \pm 0.9$ & $3.7 \pm 0.16$ & 0.62 & 99.0 \\
\hline F5 & $150.35 \pm 0.5$ & $3.8 \pm 0.18$ & 0.57 & 97.0 \\
\hline F6 & $149.22 \pm 0.9$ & $3.6 \pm 0.18$ & 0.65 & 98.0 \\
\hline F7 & $150.37 \pm 0.1$ & $3.7 \pm 0.19$ & 0.82 & 97.22 \\
\hline F8 & $149.58 \pm 0.2$ & $3.6 \pm 0.15$ & 0.8 & 98.82 \\
\hline F9 & $150.32 \pm 0.3$ & $3.8 \pm 0.14$ & 0.64 & 99.13 \\
\hline
\end{tabular}

All the values are expressed as mean $\pm S D$, where* $n=20$ and $\# n=3$

Table 4: Evaluation parameters of oral disintegrating tablets of amlodipine besylate

\begin{tabular}{|c|c|c|c|c|}
\hline Formulation & Wetting time (sec) & Water absorption ratio & In vitro dispersion time (sec) & $\%$ of drug release ( $30 \mathrm{~min})$. \\
\hline F1 & $91.0 \pm 1.2$ & $56.2 \pm 0.2$ & $36.55 \pm 2$ & 57.90 \\
\hline $\mathrm{F} 2$ & $60.15 \pm 1.5$ & $64.2 \pm 0.5$ & $34.3 \pm 1.5$ & 67.50 \\
\hline F3 & $47.35 \pm 1.9$ & $86.6 \pm 0.2$ & $32.9 \pm 2.5$ & 80.09 \\
\hline F4 & $60.09 \pm 0.8$ & $57.14 \pm 0.3$ & $31.1 \pm 1.5$ & 76.56 \\
\hline F5 & $55.61 \pm 1.3$ & $75.0 \pm 0.1$ & $30.8 \pm 1.3$ & 81.76 \\
\hline F6 & $55.0 \pm 1.9$ & $87.5 \pm 0.3$ & $29.5 \pm 1.6$ & 93.72 \\
\hline F7 & $40.20 \pm 1.7$ & $53.3 \pm 0.4$ & $30.3 \pm 1.5$ & 74.50 \\
\hline F8 & $38.94 \pm 1.9$ & $73.33 \pm 0.5$ & $29.80 \pm 2$ & 85.29 \\
\hline F9 & $24.48 \pm 1.1$ & $92.85 \pm 0.9$ & $28.2 \pm 2.2$ & 98.92 \\
\hline
\end{tabular}

All the values are expressed as mean $\pm S D$, where $n=3$.

Wetting time evaluation was used to predict the penetration of medium into the structure of oral disintegrating tablets. The results of wetting time evaluation were shown in table 4 . The wetting time of all the formulations was found to be in the range of $24.48 \pm 1.1$ to $91.0 \pm 1.2 \mathrm{sec}$. Water absorption ratio was important parameter for understanding the capacity of disintegrant to swell in the presence of a little amount of water. The difference in water absorption ratio among the formulations was due to water uptake and swelling behaviour of superdisintegrants. Water absorption ratio of all the formulation was found to be in the range of $56.2 \pm 0.2$ to $92.85 \pm 0.9$. In vitro dispersion time is used to measure the time required by the tablets to produce complete dispersion. The most important parameter that needs to be optimized in the development of oral disintegrating tablets is the disintegration time of the tablets. As the concentration of super disintegrant increases the disintegration time decreases. In vitro dispersion time of all the formulated tablets was found to be within $40 \mathrm{sec}$. Fast disintegration was observed with crospovidone as it has very high capillary activity and hydration capacity. The water uptake stretches out the folded molecular chains lying between the crosslinks, causing an instant expansion of the polymer. The increase of volume creates an internal pressure exceeding that of tablet strength, which resulted in fast disintegration of tablet. The dissolution study of oral disintegrating tablets was performed in $0.01 \mathrm{~N}$ hydrochloric acid using USP type II apparatus at $75 \mathrm{rpm}$. The comparative drug release profile was shown in fig. 2 .

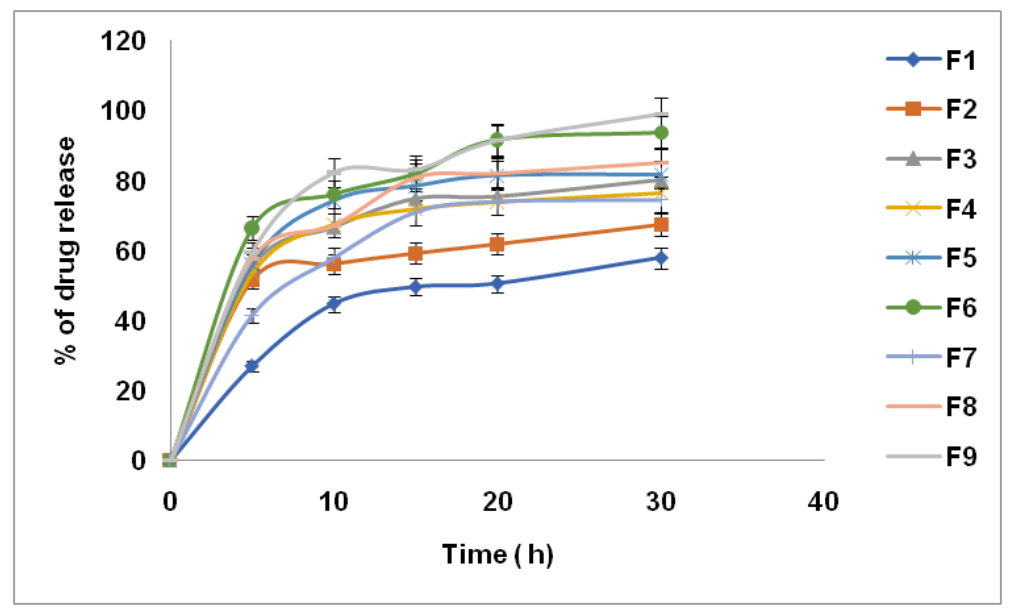

Fig. 2: Comparative in vitro dissolution profile of all the formulations (mean $\pm S D, n=3$ )

The dissolution rate was found to be comparatively less for the formulations containing sodium starch glycolate. The maximum increase in the dissolution rate was observed with crospovidone. The order of dissolution rate with various superdisintegrants was found to be crospovidone>croscarmellose sodium $>$ sodium starch glycolate. The maximum percentage of drug release was found in F9 formulation containing $4 \%$ of crospovidone, which shows $82.2 \%$ of drug release at the end of $10 \mathrm{~min}$ and $98.92 \%$ at the end of $30 \mathrm{~min}$. Based on above results formulation F9 was selected as best formulation. 


\section{FTIR studies}

The results of FTIR spectrum of pure amlodipine besylate and optimized formulation F9 was shown in fig. 3 and 4 respectively.
The characteristic peaks of the drug were observed in the spectra of drug and optimized formulation F9 indicates that there is no interaction between the drug, super disintegrant and other excipients.

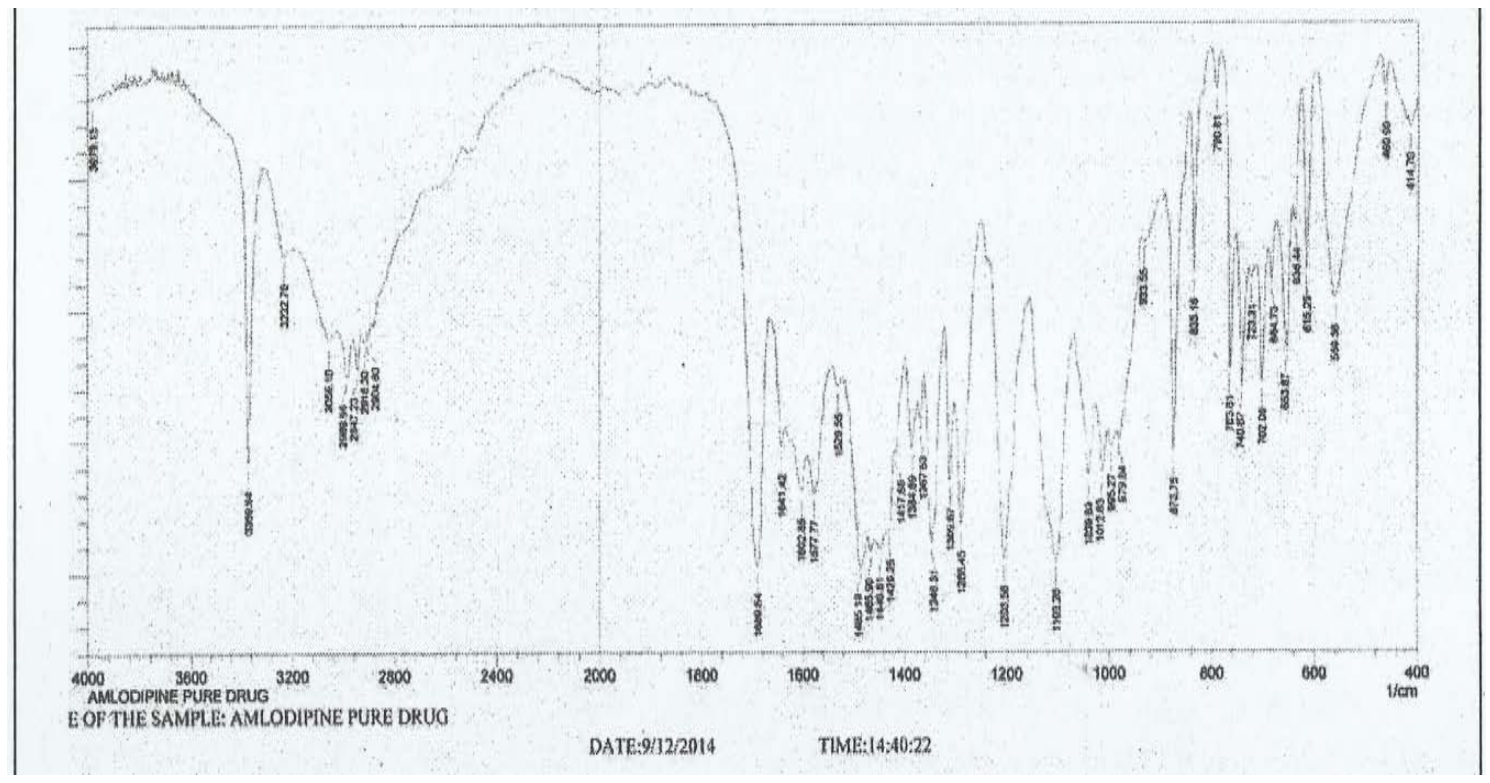

Fig. 3: FT-IR spectrum of pure amlodipine besylate

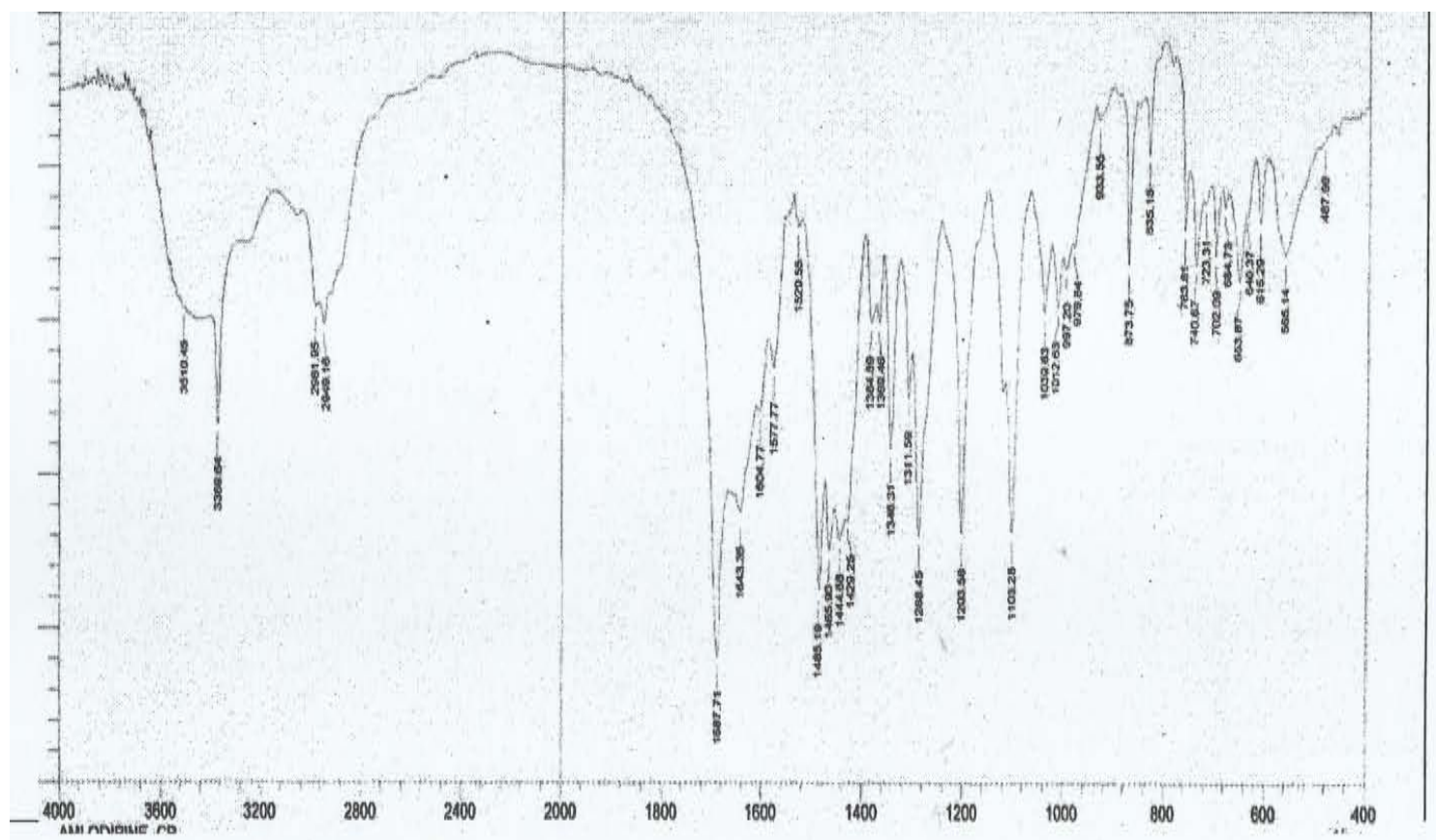

Fig. 4: FT-IR spectrum of oral disintegrating tablet of amlodipine besylate (F9)

\section{CONCLUSION}

Oral disintegrating tablets of amlodipine besylate were successfully prepared by direct compression method using crospovidone, croscarmellose sodium and sodium starch glycolate. All the oral disintegrating tablets possessed good micromeritic, physicochemical and dissolution properties. Among the nine formulations prepared, the formulation F9 containing 4\% of Crospovidone gave higher in vitro drug release of $98.92 \%$ at the end of $30 \mathrm{~min}$. The developed oral disintegrating tablets may provide quick onset of action with improved oral bioavailability and enhanced patient compliance and therapeutic efficacy.

\section{ACKNOWLEDGMENT}

The authors are thankful to Dr. M. Chinna Eswaraiah, Principal and to the management of Anurag Pharmacy College, Ananthagiri for providing necessary facilities to carry out this work.

\section{AUTHORS CONTRIBUTIONS}

All the author have contributed equally

\section{CONFLICT OF INTERESTS}

Declared none 


\section{REFERENCES}

1. Behin SR, Punitha ISR, Suraj D. Formulation and characterization of fast disintegrating tablets of amlodipine using superdisintegrants. J Appl Pharm Sci 2012;2:118-23.

2. Mohanachandran PS, Krishna Mohan PR, Saju F, Bani KB, Babu $B$, Shalina KK. Formulation and evaluation of mouth dispersible tablets of amlodipine besylate. Int J Appl Pharma 2010:2:1-6.

3. Vineet B, Mayank B, Sharma PK. Formulation and evaluation of fast dissolving tablets of amlopdipine besylate using different superdisintegrants and camphor as a sublimating agent. Am Eur J Sci Res 2010:5:264-9.

4. Shelke PV, Dumbare AS, Gandhave MV, Jadhav SL, Sonawane, Gaikwad DD. Formulation and evaluation of rapidly disintegrating film of amlodipine besylate. J Drug Delivery Ther 2012;2:72-5.

5. Muhammad AS, Syed FA, Marium FK, Sofia A, Iqbal A Formulations of amlodipine: a review. J Pharmacetics 2016;111. Doi: $10.1155 / 2016 / 8961621$.

6. Deepthi PR, Satish KK. Formulation and evaluation of amlodipine besylate oral thin films. Int J Pharma Sci Res 2016;7:199-205.

7. Shireen B, Syed AAB, Shazia F. Formulation and invitro evaluation of mouth dissolving tablets of amlodipine and rosuvastatin. Int J Curr Pharm Res 2015;7:88-91.

8. Nirav VP, Sachin C, Chintan Aundhia, Seth AK. Formulation and evaluation of amlodipine besylate orally disintegrating tablet. Indo Am J Pharma Res 2011;2:146-52.
9. Vijaya VCS, Vidyavathi M. Preparation and in vitro characterisation of bosentan monohydrate mucoadhesive microspheres. Eur J Pharma Med Res 2016;3:340-50.

10. Pratik SD, Sushma V, Puja S. Fast dissolving tablet using solid dispersion technique: a review. Int J Curr Pharm Res 2017;9:1-4.

11. Harekrishna R, Kirti RP, Sisir N, Sanjay KP, Debendra KM. Design of fast dissolving amlodipine besylate tablet formulations. Asian J Pharm 2012;6:51-9.

12. Asmaa AB. Formulationn optimization and evaluation of simvastatin rapidly dissolving tablets. Int J Appl Pharma 2018;10:270-3.

13. Sudhir B, Vinay J, Jar RC, Ashish M, Suman J. Formulation and evaluation of fast dissolving tablets of aceclofenac. Int J Drug Delivery 2010;2:93-7.

14. Kuchekar B, Badhan A, Mahajan H. Mouth dissolving tablets of salbutamol sulphate: a novel drug delivery system. Indian Drugs 2004;41:592-8.

15. Ashwini R Madgulkar, Bhalekar, Rahul RP. Formulation design and optimization of novel taste masked mouth-dissolving tablets of tramadol having adequate mechanical strength. AAPS PharmSciTech 2009;10:574-81.

16. Rashmi D, Ashish P, Sanjay N. Formulation and evaluation of mouth dissolving tablet containing amlodipine besylate solid dispersion. Int J Chem Tech Res 2010;2:706-15. 